\title{
Pembangunan Sistem Database Desain Batik
}

\author{
Maria Nila Anggia Rini ${ }^{1}$, Widi Hapsari ${ }^{2}$, Nugroho Agus Haryono ${ }^{3}$ \\ Informatika, Universitas Kristen Duta Wacana \\ Jl. Dr. Wahidin S 5-25, Yogyakarta \\ 11nila@staff.ukdw.ac.id \\ ${ }^{2}$ widi@ staff.ukdw.ac.id \\ ${ }^{3}$ nugroho@staff.ukdw.ac.id
}

\begin{abstract}
Abstrak - Salah satu kekayaan budaya yang perlu dilestarikan adalah batik. Batik memiliki motif yang beragam, dimana masing-masing memiliki filosofi dan nilai luhur. Motif batik terus dikembangkan dan dimodifikasi, bahkan diciptakan desain-desain baru. Desain yang telah diciptakan seyogyanya tersimpan dengan baik, sehingga dapat dikenal sampai masa yang akan datang. Teknologi informasi memiliki peran dalam pelestarian salah satu warisan budaya batik. Pelestarian dilakukan salah satunya melalui penyimpanan desain batik yang tidak terpengaruh oleh usia dengan cara digitalisasi dokumen. Program Pengabdian kepada Masyarakat yang dilaksanakan oleh penulis yaitu pendokumentasian desain batik secara digital dan pembangunan sebuah sistem untuk menyimpan dokumen tersebut yang dapat diakses sewaktuwaktu. Dengan demikian ada dua tahap utama yang dikerjakan yaitu pengambilan data gambar desain milik Museum Batik Yogyakarta sebagai mitra dan pembangunan sistem database yang dapat mengakses baik input maupun output data gambar. Sistem database desain dibangun dan dapat diakses tanpa kendala waktu dan tempat serta saat ini berfokus pada kepentingan internal, sehingga sistem yang dikembangkan berbasis web dengan pengguna pihak Museum Batik Yogyakarta. Partisipasi Museum Batik Yogyakarta dalam hal ini memberikan dukungan pada kegiatan Pengabdian kepada Masyarakat berupa penyediaan sumber daya yaitu data gambar desain batik.
\end{abstract}

\section{Kata kunci-batik, dokumen digital, sistem database.}

berbeda dengan daerah lain. Sebuah karya batik yang diciptakan mengandung makna dan nilai-nilai luhur. Proses penciptaan tersebut dilakukan dengan memperhatikan teknik pembuatan batik. Faktor-faktor yang mempengaruhi pembuatan produk batik antara lain bahan baku batik, peralatan pembuat batik dan jenis prosesnya, selain faktor sejarahnya, maupun makna serta maksud dan tujuan pembuatan batik [1]. Berbagai motif batik sudah sangat dikenal di masyarakat luas, misalnya batik Parang, Kawung, Truntum, Semen dan masih banyak lagi. Unsur religi, politik, sosial, dan budaya dalam motif, warna, alur, pola, isen-isen, fungsi, teknik, proses, serta penyajian menjadi
Abstract - One of the cultural wealth that need to be preserved is batik. Batik has a variety of motifs, each of which has a philosophy and value. Batik motifs are developed and modified, and even new designs are created. The designs that have been created should be stored properly, so that they can be known in the future. Information technology has a role in the preservation of one of the cultural heritage of batik. One of the ways is storing batik designs that are unaffected by age by digitizing documents. Implementation of the Community Service Program is making digital batik design documents and building a system to store these documents which can be accessed any time. Thus, there are two main stages that are taking pictures of batik designs belonging to the Yogyakarta Batik Museum as a partner and the development of a database system that can access both input and output image data. The design database system was built and can be accessed without time and place constraints and currently focuses on internal interests. So the web-based system is developed for Yogyakarta Batik Museum. The participation of the Yogyakarta Batik Museum is providing resources in the form of batik design image data for Community Service activities.

\section{PENDAhUluan}

Batik merupakan salah satu warisan kebudayaan yang dimiliki Indonesia. Batik yang berasal dari suatu daerah memiliki ciri yang

alasan batik terbukti menarik untuk didokumentasikan dari aspek pengembangannya dengan basis potensi unggulan dan kearifan lokal [2].

Batik yang merupakan kekayaan bangsa tentu harus dikelola dan dipelihara dengan baik oleh pemerintah dan tentu saja didukung oleh masyarakat. Salah satu peranan pemerintah kepada pembatikan Indonesia melalui Balai Besar Kerajinan dan Batik bersifat teknis yaitu mengadakan percobaan-percobaan mendesain batik, motif dan warna. Sifatnya menyempurnakan yang telah ada dan menciptakan sesuatu yang baru, kemudian dikembangkan untuk masyarakat pembatik [3]. Semua unsur baik komunitas, 
masyarakat dan pemerintah diharapkan memiliki peran aktif untuk mempertahankan bahkan mengembangkan karyakarya desain.

Bidang ilmu Teknologi Informasi dapat berkontribusi terhadap pengembangan terkait batik. Kontribusi tersebut misalnya dikembangkannya sebuah sistem untuk membuat desain batik. Seperti misalnya sistem desain batik Parang dibangun secara interaktif dengan memanfaatkan ornamen motif yang disimpan dalam database. Hasil yang diperoleh adalah bermacam-macam desain motif Parang berdasarkan ornamen hasil pembentukan kurva Bezier [4]. Bentuk kontribusi penggunaan teknologi informasi yang lain dengan sasaran masyarakat yang lebih umum dan lebih luas misalnya pembuatan video pembelajaran membuat batik, yang menunjukkan bahwa dengan menggunakan media video maka penyampaian materi menjadi lebih menarik dan meningkatkan minat terhadap batik [5]. Implementasi teknologi informasi berupa video pembelajaran ini bermanfaat untuk masyarakat yang ingin melihat cara membuat batik terlebih dahulu sebelum mereka terjun langsung melalui pelatihan di lokasi pembuatan batik.

Batik diciptakan di berbagai tempat di Indonesia. Masing-masing daerah memiliki karakteristik motif yang berbeda. Batik tidak hanya terkait dengan bidang kebudayaan namun juga bidang yang lain. Batik dapat menjadi salah satu daya tarik pariwisata. Melalui pemanfaatan teknologi digital berbasis komputer grafis dalam pengembangan motif batik diharapkan dapat menjadi inovasi desain dan efisiensi dalam mengeksplorasi keunggulan, keunikan serta gagasan untuk pengembangan motif batik dan dapat meningkatkan industri batik [6].

Suatu daerah biasanya terdapat komunitas atau instansi yang memiliki perhatian terhadap batik, termasuk di Yogyakarta. Museum Batik Yogyakarta merupakan salah satu museum yang menyimpan koleksi batik khususnya motif Pesisiran, Yogyakarta, Solo, dan Jawa Tengah. Selain koleksi batik, terdapat juga koleksi berupa macam-macam peralatan membatik. Museum Batik Yogyakarta merupakan sebuah tempat untuk menambah pengetahuan mengenai batik dan perkembangannya. Hal ini dapat ditunjukkan dari visi dan misinya yaitu melestarikan teknik dan pengetahuan tentang batik, serta mendokumentasikan motif-motif batik yang ada. Berbagai aktifitas yang sejalan dengan pelestarian kebudayaan adalah memberikan informasi kepada masyarakat mengenai batik. Selain itu untuk mengenal lebih dalam juga dapat dilakukan pelatihan pembuatan batik dan pendampingan kepada komunitas batik. Sehingga masyarakat tidak hanya diperkenalkan pada motif batik, tetapi juga diperkenalkan dengan segala peralatan dan cara pembuatan batik.

Desain koleksi Museum Batik Yogyakarta yang saat ini dimiliki berupa desain yang digambar pada sebuah kertas.
Desain ini menjadi pola untuk dijadikan sebuah produk kain batik. Seiring dengan berjalannya waktu, terlihat koleksi tersebut mengalami kerusakan karena media untuk menuangkan desain tidak mampu bertahan dalam kondisi baik selama bertahun-tahun. Tim Pengabdian kepada Masyarakat Fakultas Teknologi Informasi UKDW bermaksud memberi dukungan agar koleksi yang merupakan salah satu warisan budaya ini tetap dapat dilestarikan dan dikenal oleh generasi yang akan datang. Bentuk dukungan tersebut merupakan hasil pemikiran untuk mengatasi masalah media penyimpanan desain batik dari bentuk fisik desain pada kertas menjadi dokumen digital. Program PkM tim FTI ini merupakan program berkelanjutan yang berfokus kepada peminatan tentang batik. Karena permasalahan pandemi yang saat ini dihadapi, maka periode berikutnya yang direncanakan merupakan program pengembangan sistem yang dapat dimanfaatkan oleh komunitas dan masyarakat pecinta batik.

\section{MASALAH}

Permasalahan yang dihadapi oleh mitra program Pengabdian Kepada Masyarakat yaitu Museum Batik Yogyakarta, yang pertama adalah bagaimana generasi di masa depan dapat mengenal desain yang pernah diciptakan dan memahami filosofi batik yang merupakan koleksi milik Museum Batik Yogyakarta. Dan permasalahan yang kedua adalah bagaimana koleksi batik ini dapat disimpan dalam bentuk digital sehingga dapat memberikan solusi atas terjadinya kerusakan dokumen fisik. Selanjutnya dokumen digital tersebut dapat disimpan dalam sebuah sistem agar dapat diakses pada sewaktu-waktu dengan mudah.

\section{Metode PELAKSANAAN}

Untuk menyelesaikan masalah yang dihadapi yaitu keterbatasan penyimpanan gambar dalam bentuk gambar sehingga rawan akan kerusakan, maka desain-desain batik milik MBY disimpan dalam bentuk dokumen digital. Digitalisasi dokumen/arsip adalah salah satu cara proses mengubah dokumen/arsip konvensional dalam berbagai bentuk dan media menjadi dokumen/arsip elektronik/digital. Program digitalisasi dokumen/arsip dilaksanakan sebagai upaya mempertahankan aksesibilitas sehingga dapat memberikan akses seluas-luasnya bagi masyarakat [7]. Proses digitalisasi dapat menghasilkan file gambar yang dapat diperbesar, diperbaiki, diberi tambahan, diperkecil, dan lain-lain. Hasil digitalisasi ini dapat disimpan dan digunakan sewaktu-waktu [8]. Dengan adanya dokumen digital tersebut, maka diharapkan mampu mendukung pelestarian budaya untuk generasi yang akan datang. 
Teknologi informasi yang diimplementasikan dapat mendukung perubahan cara penyimpanan data gambar. Selanjutnya untuk dapat dengan mudah data tersebut diakses, maka dibangun sebuah sistem database. Terdapat tujuh tahap untuk membangun dokumentasi digital [9], yaitu :

\section{a. Resource Content Research \\ b. Digitization \\ c. Evaluation \\ d. Data Management \\ e. Content and Publishing \\ f. Metadata Design and Input}

Dalam pengabdian ini, proses digitalisasi menggunakan tujuh proses tersebut. Dengan data digitaliasi, selain desain batik dapat disimpan dengan baik, dapat pula digolongkan berdasarkan jenisnya, misalnya: corak, motif, dan daerah asal. Sehingga pengetahuan (knowledge) yang terkandung didalamnya akan tersimpan dengan baik dan tidak akan hilang. Tahapan tersebut di atas merupakan proses untuk melakukan pembangunan sistem database. Dimana sistem tersebut harus disesuaikan dengan kebutuhan pengguna. Pemanfaatan database dalam sebuah aplikasi memungkinkan untuk dapat menyimpan data atau melakukan perubahan dan menampilkan kembali data tersebut dengan cepat dan mudah [10]. Dalam melakukan desain dan pemodelan database kebutuhan pengguna dilihat dari kebutuhan informasi [11].

Selain langkah-langkah pembangunan sistem seperti telah disebutkan di atas, perlu disiapkan data sebagai masukan dari sistem yang dibangun. Data yang diolah merupakan desain yang digambar pada lembar kertas. Desain tersebut kemudian difoto dengan menggunakan kamera, untuk menjadi data digital. Data yang menyertai gambar desain, misalnya asal, sejarah dan deskripsi diinputkan oleh mitra melalui fasilitas yang disediakan oleh sistem untuk proses input data tersebut. Data kamera berupa file berupa data gambar dengan format jpg, sehingga langsung dapat digunakan sebagai data input karena sistem mampu membaca gambar dengan ukuran atau dimensi yang berbeda. Database diperlukan dalam menyusun data dan menvisualisasikan laporan sehingga data yang ada dijadikan sebuah informasi [12].

Pengabdian Kepada Masyarakat dilaksanakan oleh tim FTI UKDW bersama mitra Museum Batik Yogyakarta berlokasi di jl. Sutomo 13A Yogyakarta. Kegiatan yang diawali dengan survey kebutuhan telah dilakukan sejak bulan Maret, dan dijadwalkan selesai pada akhir September.

\section{HASIL DAN PEMBAHASAN}

Sistem database yang dibangun memerlukan 2 tahap kegiatan. Tahapan proses yang dijalankan tersebut didapatkan hasil berupa data gambar digital dan sistem desain database. Periode pengambilan gambar dilakukan pada masa pandemi sebelum diberlakukan PPKM, sehingga tahap pengambilan gambar dapat berjalan dengan baik. Selanjutnya pembuatan sistem dilakukan secara remote, sehingga masa PPKM tidak mempengaruhi kegiatan tahap kedua. Komunikasi yang perlu untuk memastikan kebutuhan sistem dilakukan secara daring.

Pada awalnya, desain yang digambar pada lembar kertas difoto dengan menggunakan kamera. Lembaran kertas berisi desain memiliki beberapa ukuran gambar. Untuk ukuran gambar yang memiliki panjang lebih dari $150 \mathrm{~cm}$ belum dapat terjangkau pada kegiatan PkM ini. Hal tersebut disebabkan karena peletakan gambar yang cukup tinggi yang tidak memungkinkan untuk diambil dan dipasang kembali dengan mudah. Sehingga hanya gambar dengan ukuran kurang dari $150 \mathrm{~cm} \times 150 \mathrm{~cm}$ yang dipakai sebagai data untuk sistem.

Pengambilan data gambar dibuat dalam 2 versi. Versi pertama adalah gambar tanpa dilakukan perubahan apapun, sedangkan untuk versi kedua data gambar dilakukan cropping untuk mendapatkan gambar desain tanpa ada background atau gambar lain di sekitar yang tidak dibutuhkan. Setelah proses cropping, rata-rata dimensi gambar menjadi kurang lebih 500x1000 pixel. Jumlah desain yang difoto mencapai 500 gambar, dengan variasi desain segiempat atau desain pada pola berbentuk segitiga. Meskipun jumlah ini belum mencakup semua desain yang ada di MBY, namun sudah cukup memadai untuk input data pada sistem. Gambar 1 merupakan contoh desain karya MBY. Semua gambar desain yang diambil menggunakan kamera ini diserahkan kepada pihak mitra.
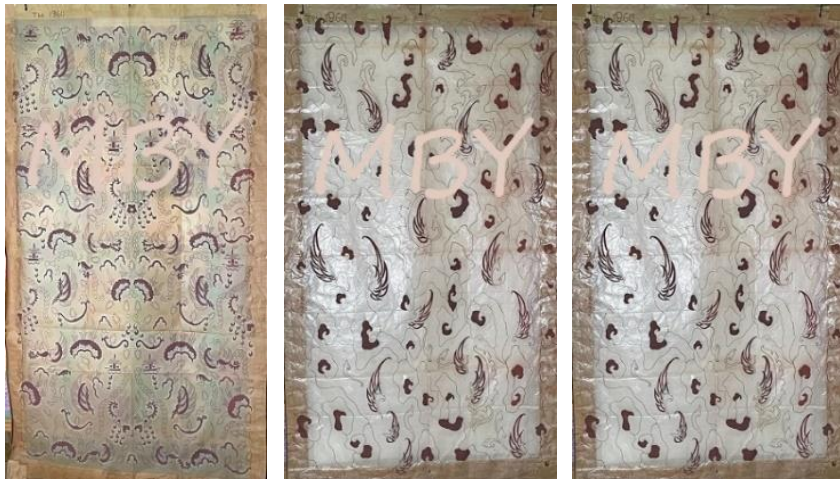

Gambar 1. Gambar desain Batik milik MBY

Desain batik MBY sangat beragam misalnya motif Semen, motif bunga dilengkapi dengan kupu, wayang, dan sebagainya. Foto-foto ini diunggah di google drive untuk sementara sebelum sistem database selesai dibangun. Lokasi penyimpanan di drive dibagikan kepada pengelola MBY.

Hasil identifikasi kebutuhan sistem yang dilakukan tim dengan pihak mitra menghasilkan sebuah rancangan sistem database. Dari rancangan tersebut kemudian dilanjutkan 
dengan pembuatan sistem yang membutuhkan waktu kurang lebih 1 bulan. Sistem desain database dibangun dengan tabel yang berisi field id_motif_batik, asal_batik, sejarah_batik, deskripsi_batik dimana field tersebut terkait dengan penyimpanan motif batik. Tabel yang lain yang digunakan untuk penyimpanan gambar batik yaitu id_batik dan nama_gambar. Dan tabel untuk pengelolaan pengguna dengan field name, username, email, password.

Foto-foto desain yang awalnya disimpan sementara di google drive, selanjutnya diunggah ke sistem desain database yang telah selesai dibangun. Sistem diberi nama Digibatiks yang diambil dari kata digital dan batik, yang tampilan awalnya dapat dilihat pada Gambar 2.

Digibatiks

Selamat Datang Di Digibatiks

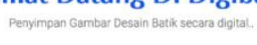

$\cos x \sin$

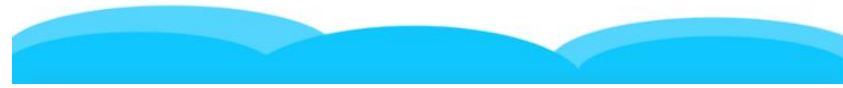

Gambar 2. Landing Page Digibatiks

Sistem dilengkapi dengan halaman login untuk admin yang memiliki akses penuh untuk menjalankan semua menu yang disediakan. Pengguna yang saat ini merupakan admin sistem memiliki hak akses untuk memasukkan data baru, mengubah dan menghapus data yang sudah disimpan. Tangkapan layar pengelolaan pengguna dapat dilihat pada Gambar 3.

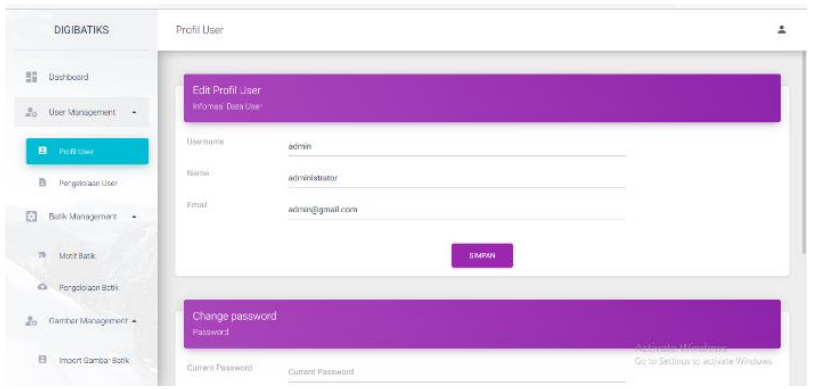

Gambar 3. Halaman Pengelolaan Pengguna

Berikutnya yang merupakan fasilitas utama dari sistem adalah memasukkan data motif, gambar beserta informasi yang menyertai setiap desain. Gambar-gambar batik yang diinputkan masuk dalam salah satu kategori motif yang ditentukan. Dari fasilitas yang disediakan menunjukkan sistem dapat melakukan pengelolaan motif dan gambar batik serta pengelolaan gambar. Menu pengelolaan batik diawali dengan menambahkan nama motif baru beserta deskripsinya seperti terlihat pada Gambar 4.

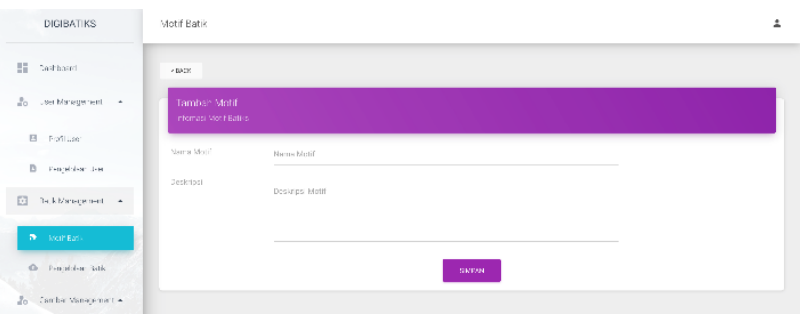

Gambar 4. Halaman Penambahan Motif Batik

Motif maupun deskripsi yang telah ditambahkan dapat diubah maupun dihapus. Berikutnya pada Gambar 5, dapat dilihat tombol-tombol yang dapat dijalankan terkait dengan pemeliharaan data motif batik.

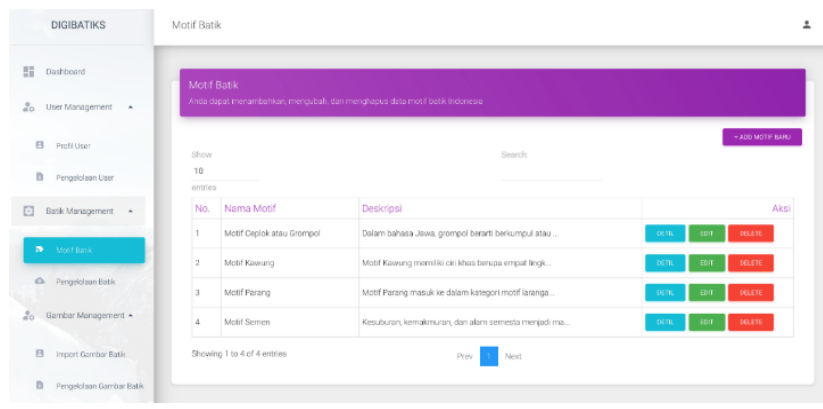

Gambar 5. Halaman Pengelolaan Motif Batik

Setelah data motif dimasukkan, selanjutnya pengguna melakukan entri data nama batik, pilihan motif, beserta asal, sejarah dan deskripsi. Proses ini dilakukan masih pada bagian pengelolaan Batik. Data yang telah tersimpan dapat dilakukan perubahan melalui fasilitas edit dan delete seperti pemeliharaan motif. Tangkapan gambar ditunjukkan pada Gambar 6. Gambar batik yang disiapkan sebagai data input telah dilakukan digitalisasi sebanyak 500 gambar, sedangkan motif dan deskripsi disiapkan oleh pengguna yang saat ini belum dapat diperoleh secara lengkap. Namun demikian sistem sudah dapat digunakan jika data-data tersebut sewaktu-waktu telah siap.

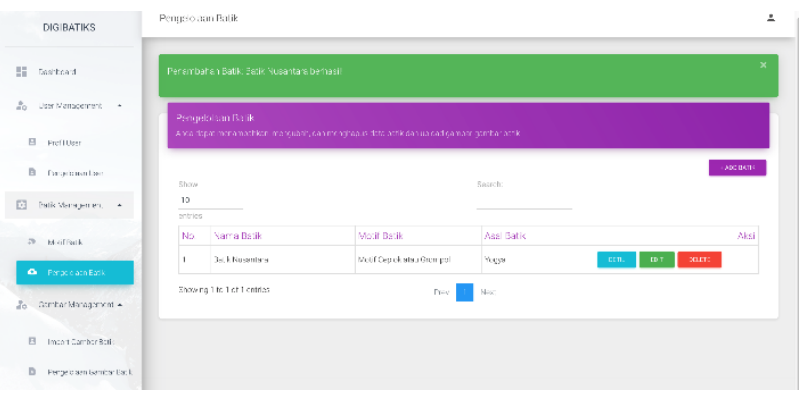

Gambar 6. Halaman Pengelolaan Gambar Batik 
Sistem mampu melakukan entri data dengan jumlah gambar desain batik yang cukup banyak melalui fasilitas impor gambar batik. File yang diterima adalah file yang telah dikompresi dengan ekstensi .zip. Fasilitas ini dibangun dengan pertimbangan karena jumlah gambar yang dimiliki pihak museum sangat banyak maka diberikan kemudahan untuk entri data, seperti terlihat pada Gambar 7.

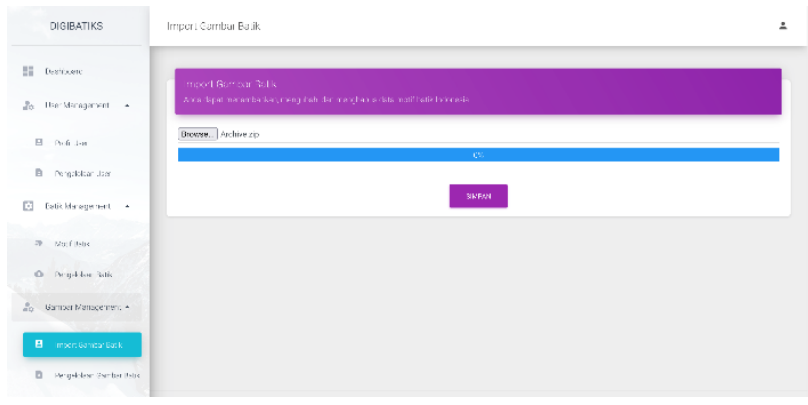

Gambar 7. Halaman Impor Gambar

Proses impor gambar dapat dilakukan pada menu Pengelolaan Gambar yang selanjutnya gambar-gambar tersebut dapat dilihat oleh pengguna seperti yang ditunjukkan pada Gambar 8. Gambar-gambar yang telah diimpor kemudian akan muncul dan dipilih pada menu pengelolaan batik. Ketika sebuah desain batik dipilih, maka desain tersebut dapat dilengkapi dengan deskripsi yang dimiliki oleh MBY.

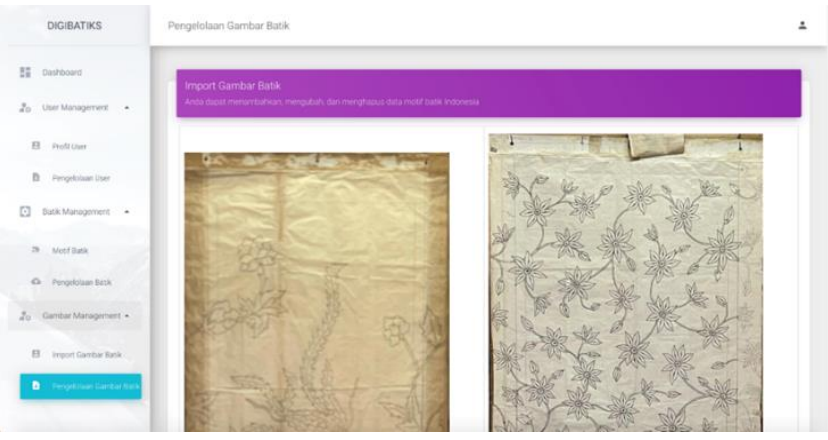

Gambar 8. Halaman untuk Melihat Hasil Impor Gambar

Sistem Digibatiks dilengkapi dengan sebuah Dashboard. Dashboard Digibatiks menyajikan visualisasi informasi penting mengenai hasil monitoring input jumlah data gambar terpakai. Pada bagian ini tampak jumlah gambar yang sudah dipilih oleh pengguna untuk dilengkapi informasinya dan jumlah gambar yang masih dalam bentuk kumpulan data tersimpan. Jika pilihan pada dashboard ini di-klik, maka layar akan menampilkan halaman yang lebih spesifik yaitu halaman pengelolaan batik atau halaman pengelolaan gambar yang telah diimpor. Tampilan dashboard dapat dilihat pada Gambar 9.

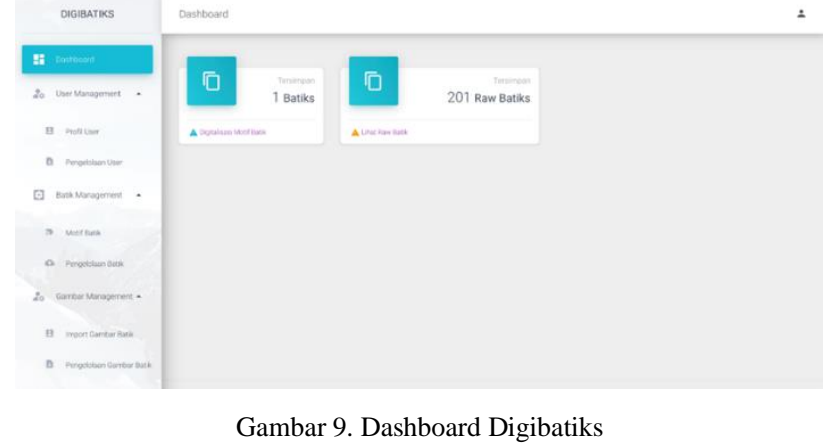

Demikian hasil yang diperoleh dari kegiatan PkM. Dari hasil tersebut menunjukkan bahwa Sistem Digibatiks mampu melakukan pengelolaan untuk gambar desain batik milik Museum Batik Yogyakarta. Proses berawal dari input data gambar melalui impor file. Dilanjutkan dengan pengelolaan batik yang mampu melakukan proses penyimpanan, pengubahan dan penghapusan terhadap motif kemudian dilanjutkan dengan pemeliharaan data gambar desain batik. Data gambar batik juga dapat dilakukan perubahan dan penghapusan apabila diperlukan setelah proses penyimpanan. Sistem dilengkapi dengan pengelolaan pengguna serta dashboard sebagai visualisasi informasi data gambar yang dikelola.

Pihak Museum Batik memberikan apresiasi terhadap program kerjasama PkM berupa pembuatan sistem database ini, melalui kuesiner yang telah disampaikan. Kendala pandemi menyebabkan MBY menghentikan operasional untuk sementara, dan berharap implementasi program ini dapat bermanfaat dengan lebih optimal setelah kondisi memungkinkan. Sistem ini diharapkan dapat digunakan juga oleh instansi lain yang memiliki kebutuhan yang sama tentang penyimpanan data gambar.

\section{KESIMPULAN DAN SARAN}

Program PkM yang diusulkan yaitu pembuatan sistem database desain berjalan dengan baik meskipun dilaksanakan pada masa pandemi. Dua tahap kegiatan ini telah dilaksanakan di lokasi PkM dan dilanjutkan dengan aktivitas yang tidak perlu dikerjakan di lokasi.

Tahap pertama adalah pengambilan data gambar untuk sistem dan dapat diselesaikan dengan jumlah data sebanyak 500 gambar. Tahap kedua pembuatan sistem database. Sistem yang dibuat mampu melakukan penyimpanan data berupa motif dan gambar desain beserta deskripsi untuk masing-masing desain serta proses pemeliharaan data. Data gambar dapat diimpor pada sistem Digibatiks, namun untuk kelengkapan informasi terkait gambar desain yaitu asal, sejarah dan deskripsi diiinputkan oleh pihak museum beserta data gambar desain yang lainya. 


\section{UCAPAN TERIMA KASIH}

Penulis mengucapkan terima kasih yang sebesarbesarnya kepada Lembaga Penelitian dan Pengabdian Masyarakat UKDW yang telah mendukung pembiayaan kegiatan Pengabdian kepada Masyarakat tim Fakultas Teknologi Informasi UKDW, serta kepada FTI UKDW yang telah memfasilitasi sehingga kegiatan ini dapat berjalan dengan baik. Kami juga mengucapkan banyak terima kasih kepada pengelola Museum Batik Yogyakarta yang merupakan mitra yang telah menyediakan sumber daya berupa data-data gambar batik sehingga menolong kami menyelesaikan kegiatan PkM ini.

\section{DAFTAR PUSTAKA}

[1] Paguyuban Pencinta Batik Indonesia, Batik Indonesia Mahakarya Penuh Pesona, Yogyakarta: Kakilangit Kencana, 2015.

[2] D. Nurcahyanti and T. B. Affanti, "Pengembangan Desain Batik Kontemporer Berbasis Potensi Daerah dan Kearifan Lokal," Sosioteknologi, vol. 17, no. 3, pp. 391-402, 2018.

[3] S. S. Susanto, Seni Batik Indonesia, Yogyakarta: Andi Offset, 2018.

[4] W. Hapsari and N. A. Haryono, "Pembangunan Sistem Desain Batik Parang dengan Kurva Bezier," Dinamika Kerajinan dan Batik, pp. $127-134,2020$
[5] W. Hapsari and N. A. Haryono, "Pembuatan Video sebagai Media Pembelajaran Membuat Batik," in Sendimas 2020, Yogyakarta, 2020.

[6] P. Sulistiyawati, D. I. Ihya, Ulumuddin and A. P. Azhari, "Implementasi Komputer Grafis pada Perancangan Motif Batik Papua," TANRA, vol. 7, no. 2, pp. 92-100, 2020.

[7] D. Sugiharto, "Penyelamatan Informasi Dokumen/Arsip di Era Teknologi Digital," BACA, vol. 31, no. 1, pp. 51-64, 2010.

[8] I. A. Siradjuddin, K. Sophan, A. Kurniawati and R. Triwahyuningrum, "Pembuatan dan Digitalisasi Batik Tulis Madura pada UKM Batik Bangkalan,” Layanan Masyarakat, vol. 03, no. 01, pp. 18-21, 2019.

[9] Saefurrohman and D. H. U. Ningsih, "Metode Preservation Metadata Implementation Strategies (Premis) bagi Standarisasi Dokumentasi Digital Batik Tulis Warisan Nusantara," Jurnal Teknologi Informasi DINAMIK, pp. 140-147, 2015.

[10] W. S. Prasetya, "Perancangan Model Basis Data Relasional dengan Metode Database Life Cycle," in Seminar Nasional Informatika, Medan, 2015.

[11] F. Syakti, Hutrianto and U. Ependi, "Desain dan Implementasi Pemodelan Database Industri Kecil Menengah Kota Palembang," Informatika, vol. 19, no. 1, pp. 70-78, 2019.

[12] N. Setiawan, "Integrasi Database untuk Visualisasi dan Laporan pada Divisi Humas Universitas Swasta di Surabaya," Tirta, vol. 7 , no. 1, pp. 1-3, 2019. 